\title{
Optimal harvest timing of Prangos ferulacea (L.) Lindl : effects of phenology stages, elevation and type of plant factors on forage quality
}

\author{
Z. Mohebi ${ }^{1 *}$, G. A. Heshmati ${ }^{1}$, F. Sefidkon ${ }^{2}$, M.A. Zare Chahouki ${ }^{3}$
}

${ }^{1}$ Department of Range Management, Faculty of Range and Watershed Management, Gorgan University of Agricultural Sciences \& Natural Resources, Basij Sq., Gorgan, Golestan Province, Iran. *Corresponding author: za.mohebi@gmail.com

${ }^{2}$ Research Institute of Forests and Rangelands, P.O.Box: 13185-116, Tehran, Iran

${ }^{3}$ Department of Rehabilitation of Arid and Mountainous Regions, Natural Resources Faculty, University of Tehran, Karaj, Iran, P.O.Box: 31585-4314

\begin{abstract}
Prangos ferulacea (L.) Lindl (Umbelliferae) is a forage and medicinal plant that grows in central Asia. This study was carried out to determine the nutritive value of $P$. ferulacea, which is often used as animal fodder. Plant samples collected from two elevation levels (2200- $2900 \mathrm{~m}$ ) of western Iran were evaluated at two stages of maturity, flowering and seeding stage for fertile plants and at 42 and 62 days after leaf emergence for infertile individuals. The nutrient composition, including metabolizable energy (ME) and digestible dry matter (DMD), crude protein (CP), water-soluble carbohydrate (WSC), acid detergent fibre (ADF), natural detergent fibre (NDF) and crude fibre (CF) contents were measured by near infrared reflectance spectroscopy (NIRS) technology. The stage of maturity and type of plant (fertile and infertile) were significantly related to the $\mathrm{CP}$, ME, NDF and ADF contents. Based on multivariate analysis (two-way ANOVA), the phenology, individual and phenology $\times$ individual interaction factors had the highest effect on nutrient composition parameters. Based on our findings, we proposed that infertile plants at 42 days after leaf emergence stage represent the best quality fodder. Elevation level did not significantly affect forage quality.
\end{abstract}

keywords: Phenology, elevation, individuals, forage quality, NIRS 


\section{Introduction}

Forage plants on rangeland play an important role in improving animal performance and can resolve forage and fodder issues for many countries. The nutritional characteristics of these crops are necessary for evaluation and determination of their economic and biological values. A total of 363 species and 114 genera of apiaceae are known from Iran, of which 114 species and 12 genera are endemic (Rechinger and Hedge, 1987; Ajani et al., 2008). The genus Prangos includes 30 species, 15 of which grow wild in many regions of Iran which five are endemic (Mozaffarian, 1996). Prangos ferulacea is found in the Balkans, Italy, Sicily, W. Syria, Caucasia, Turkey and in 13 provinces of Iran (Ghahreman, 1997). This species is well-known for their economic importance in the form of diverse essential oils and high forage quality (Ayres et al., 1994; Sefidkon et al., 1998; Coskun et al., 2004; Razavi, 2012). Due to the essence in aerial parts, the species is not grazed directly and is used as winter fodder (Moghimi, 2004). The forage quality of plant is comparable to alfalfa. Its crude protein is less than that for alfalfa, but its metabolizable energy is higher (Coskun et al., 2004). The biological properties of $P$. ferulacea show that it is polycarpic perennial (polycarpic plants flower and fruit more than once in their lifetimes) (Reuther, 2013).

P. ferulacea individuals seed 5\% to $70 \%$ annually; this species has both fertile and infertile individuals in their growth environment (Gheitoori, 1997). Plants show wider physiological and ecological responses, functional diversity, growth rates, productivity, population and community dynamics at different scales (Ackerly et al., 2000). When they are subject to less than ideal sub-optimal growing conditions such as waterlogging, drought, high/low temperatures, and excessive/extreme soil salinity, they are considered to be under stress and this stress directly effects production and yield (Gursoy et al., 2012). Environmental stresses also trigger simultaneous up- and down-regulation of a large number of genes through close control of genetic behavior (Genctan, 2012).

Previous studies have indicated that plant forage quality depend on the stage of maturation, environmental conditions and type of species. (Dierig et al., 2006; Panahi et al., 2012; Milošević et al., 2013) and the nutritive value reduced in the final stages of maturation (Arzani et al., 2012; Valipoor Dastenai et al. 2012; Oktay and Temel, 2015). Troelsen and Campbell (1969) reported that as plants mature, animal performance is reduced, partly because of lowered content of digestible energy (DE) in the forage. The difference between individuals (fertile and infertile) means that harvest for forage conservation should optimize both types of plant and forage quality. It is important to analyze the forage quality at the phenological stages and different elevations for individual plants. The increased power and widespread use of personal computers and the concomitant development of multivariate statistics in the field of chemometrics have resulted in increased use of near infrared reflectance spectroscopy (NIRS) as an alternative to traditional analytical methods for determining nutritive value of forage. There are advantages to NIRS over conventional laboratory analytical methods which they are: speed, simplicity of sample preparation, multiplicity of analyses with one operation, and non-consumption of the sample (so that it can be analyzed again by the same or another procedure) and does not usually require labor-intensive sample processing, allowing for large-scale sampling. Timely decision-making on the strategic use of nutritional supplements or adjustments for ration formulation that efficiently sustain milk, meat and fiber production is also facilitated by this method. Although development of an NIRS labo- 
ratory entails significant initial start-up costs, it is relatively inexpensive in the long term (Abrams et al., 1989). As well as, it allows for the determination of multiple values (e.g. $\mathrm{CP}, \mathrm{DMD}, \mathrm{WSC}, \mathrm{ADF}$ ), $\mathrm{NDF}$ and $\mathrm{CF}$ in a single analytical procedure (Panahi et al., 2012).

The study was conducted to: (1) assess the feed value of P. ferulacea at different growth stages and at different elevations; (2) determine whether the fertility and infertility of plants of the species influence nutritional quality by NIRS and; (3) Introducing the best type of plant and harvest date for fodder.

\section{Materials and Methods}

\subsection{Study area}

This study was conducted in the Bistoon mountains of Kermanshah province in Iran (north-eastern slope at $34^{\circ} 27^{\prime} \mathrm{N}$ and $46^{\circ} 55^{\prime} \mathrm{E}$ ). The average annual temperature and annual rainfall are $11.88{ }^{\circ} \mathrm{C}$ and 650 $\mathrm{mm}$ respectively that more precipitation is snow. At altitudes from 2200 to $2900 \mathrm{~m}$. the plant grows. The site soil is classified as a Regosolic, in the upper 5 $\mathrm{cm}$ of the site soil below the litter layer, total soil nitrogen, total soil phosphorus and potassium per unit soil volume are 0.46 (\%), 37.6 (p.p.m) and 610 (p.p.m), respectively (Gheitoori et al., 1997). Field experiments were conducted during spring and summer 2014.

\subsection{Plant materials}

During annual growth, fertile and infertile plants grow together. Aerial parts of fertile and infertile plants were cut at the appearance of flowers (flowering) or $42 \mathrm{~d}$ after leaf emergence (6 May) for stage 1 and at the appearance of seeds (seeding) or $62 \mathrm{~d}$ after leaf emergence (1 June) for stage 2. Two elevations were determined for the low and high growth areas
(2200-2550 $\mathrm{m}$ and 2550-2900 m). These were cut regularly during May and June 2014 in sample areas of $50 \mathrm{~m}^{2}$ randomly replicated three times. At each maturation stage, 36 plant samples were harvested at $10 \mathrm{~cm}$ above ground level at each elevation.

Samples were dried without conditioning and were ground in a laboratory mill until they passed through a $1 \mathrm{~mm}$ pore size screen for chemical analysis.

\subsection{Experimental procedure}

NIRS analysis requires a sample to be exposed to an electro-magnetic scan over a spectral wavelength of 1100 to $2500 \mathrm{~nm}$ (near infrared). Energy in this spectral range is directed onto the sample and reflected energy is measured by the instrument. The diffuse reflection carries information which identifies the chemical bonds within the sample. The absorbance associated with chemical bonds in a forage sample form the basis of all organic material and enable identification of sugars, structural fibers, proteins, lipids and some of their component fractions. Identification requires the NIRS instrument to be calibrated to relate the spectra to chemical analysis using wet chemistry or in vivo data (e.g., digestibility and metabolisable energy) (Ulyatt et al., 1995).

The NIRS for analysis is absolutely dependent on a good-quality reference laboratory and animal data (Corson et al., 1999). metabolizable energy was calculated as $\mathrm{ME}(\mathrm{MJ} / \mathrm{kg})=(0.017 \times \mathrm{DMD} \%)-2(\mathrm{CSIRO}$, 1990), $10 \mathrm{~g}$ of ground forage of was weighed and the prepared samples were analyzed by NIRS. The accuracy of NIRS estimation of feed composition is dependent upon the data used to calibrate the instrument. After calibration of the instrument database, the parameters for $\mathrm{DMD}, \mathrm{CP}, \mathrm{WSC}, \mathrm{ADF}, \mathrm{NDF}, \mathrm{CF}$ and ME were measured. 


\subsection{Statistical analysis}

Data on nutrient composition was calculated using analysis of variance (ANOVA) and multivariate analysis of variance (MANOVA) on SPSS version 19 software. The data was tested to ensure that assumptions of normality (quartile-quartile and proportionproportion plot tests) and homogeneity of variance (Levene's test, $\alpha>0.05$ ) were met. Full factorial two-way ANOVA was run for phenology, elevation and individual treatments as fixed factors and forage quality parameters as dependent variables to examine the effects of the treatments on nutrient composition. The effect of any parameter and mutual effect of parameters (independent variables) on nutrient content (dependent variables: DMD, CP, WSC, ADF, NDF, $\mathrm{CF}, \mathrm{ME}$ ) were considered using MANOVA.

Pearson's correlation was used to detect the relationships between forage quality and environmental factors. One-way ANOVA was conducted to test for the effect of individuals (fertile and infertile) on nutritional contents because of the significant differences in the nutrient content of tissues of these two individuals. A comparison of means was carried out using Duncan's t-test to describe the nutritive parameters by stage of maturity and type of plant. The means and standard error for parameters (nutritive value) were generated by the descriptive section of the one-way method. Differences were considered to be significant at $p<0.01$ and $p<0.05$.

\section{Results and Discussions}

The probability curves in the quartile-quartile and proportion-proportion plot tests were almost linear, which confirms the assumption of data normality (Figure 1).

\subsection{Effect of elevation on forage quality of plant indi- viduals in maturity stages}

The nutrient composition of fertile and infertile plant of P. ferulacea species were assessed at two stages of maturity: (1) at flowering of fertile plants, which corresponds to $42 \mathrm{~d}$ after leaf emergence for infertile plants and; (2) seeding for fertile plants, which corresponds to $62 \mathrm{~d}$ after leaf emergence for infertile plants. The two stages of maturity were investigated at elevations of 2200-2550 m (elevation 1) and 2550-2900 m (elevation 2). There were no significant differences between forage of fertile individuals at elevation 1 (2200-2550 $\mathrm{m}$ ) and elevation $2(2550-2900 \mathrm{~m})$ in stage 1 (Table 1). For fertile individuals, the nutrient composition was not greatly affected by elevation $(p<0.05)$.

In stage 2, the DMD content of infertile individuals at elevation 2 was greater than that for infertile individuals at elevation 1 . The WSC content at elevations 1 and 2 (infertile) was lower than at elevations 1 and 2 (fertile). A significant interaction $(p<0.05)$ was observed for WSC content for all individuals; it tended to increase as elevation increased and the decline for fertile individuals was larger than for infertile individuals. The ME content of infertile plants increased as elevation increased $(p<0.05)$ (Table 1).

\subsection{Effect of type of plant on forage quality in flower- ing or $42 d$ after leaf emergence and seeding or $62 d$ after leaf emergence}

The significant differences for nutritional contents were observed in the phenology and individual treatments (Table 1). Duncan's test to determine nutritive parameters, means \pm standard error and standard error of the difference of means were carried to test the effect of phenology and individual treatments on nutritional contents (Table 2, 3). 

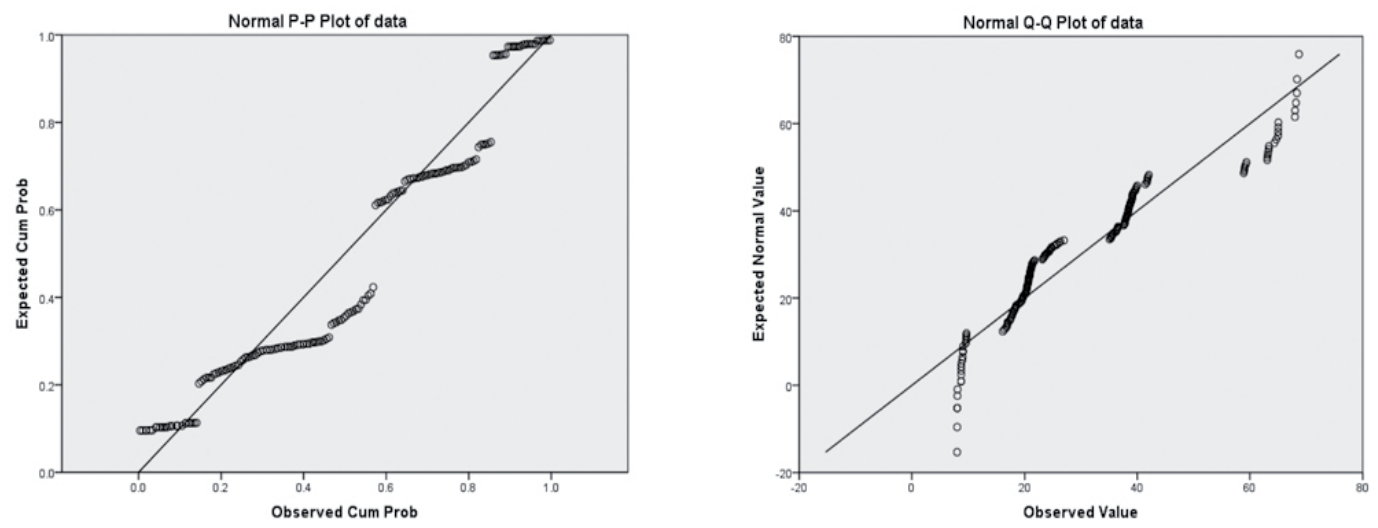

Figure 1. The assumption of data normality using Quartile-Quartile Plot and Proportion-Proportion Plot tests

Table 2 showed the nutritive composition of $P$. ferulacea at stage 1 and 2. As seen, total forage quality parameters were significantly affected $(p<0.01$, $0.05)$ by type of individual. There was a significant difference between fertile and infertile plants for DMD, WSC, ADF, CF, NDF, ME, and CP content ( $p<0.01)$. An increase was seen in infertile versus fertile plants for $\mathrm{DMD}, \mathrm{CP}$ and $\mathrm{ME}$ content and a decrease for WSC, ADF, NDF, and CF content.

Table 2 revealed that the DMD, ME and CP content of infertile plants was greater than the fertile plants; however, these contents for infertile plants were less than those for fertile plants at either elevation (Table 2). The WSC content at elevations 1 and 2 were lower for infertile plants than fertile plants. There was a significant interaction $(p<0.01,0.05)$ for WSC content versus elevation for all plants. The overall WSC increased as elevation increased, but the WSC content of fertile plants was greater than for infertile plants (Table 2).
The mean of ADF, CF and NDF contents of forage in infertile plants were significantly greater $(p<0.01$, 0.05) than for fertile plants (Table 2).

$\mathrm{DMD}, \mathrm{ME}$ and $\mathrm{CP}$ contents were significantly ( $\mathrm{P}$ $<0.01)$ affected by both maturity stage and type of plant. These contents decreased across growth stages from infertile up to fertile individuals.

The mean ADF, NDF and CF contents of forage increased from stage 1 up to stage 2 , but decreased at infertile individuals than fertile (Table 3 ).

In total of forage quality characteristics, there were significant differences $(\mathrm{P}<0.01,0.05)$ between fertile and infertile plants at growth stages 1,2. Also DMD, CP and ME consentration of infertile plantsin 42 days after leaf emergence stage were significantly $(\mathrm{P}<0.01,0.05)$ greater than infertile plants in 62 days after leaf emergence stage, in contrast, $\mathrm{ADF}, \mathrm{CF}$ and NDF contents were significantly lower. Similar results were obtained for fertile plants (Figure 2). 
Table 1. The nutrient compositions (\%) of P. ferulacea (Mean \pm Std. Error) in flowering or 42 days after leaf emergence and seeding or 62 days after leaf emergence stages

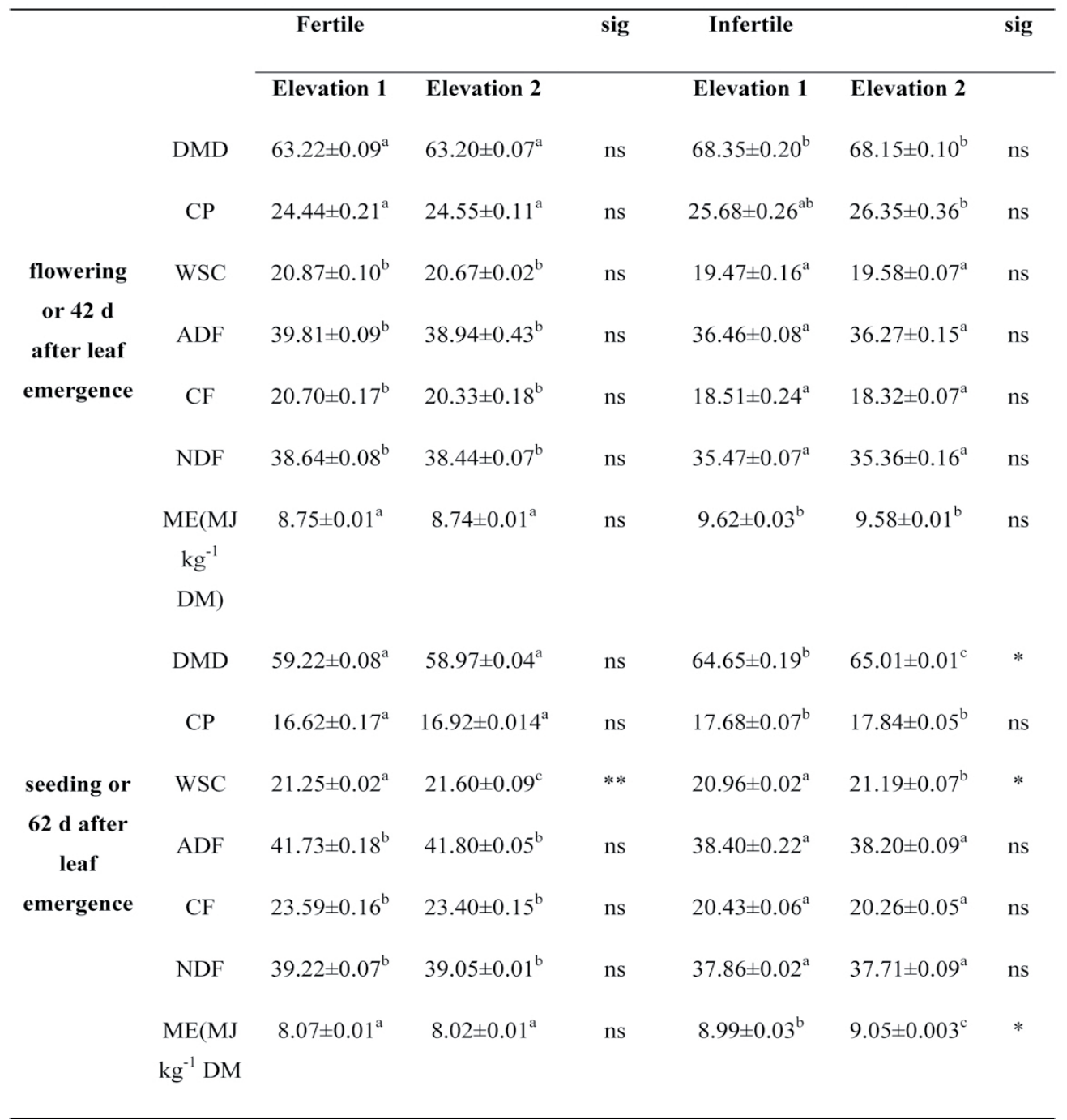

Dissimilar letters in each row indicate significant differences in the level of $\mathrm{P}<0.01 * *, 0.05^{*}$.

Elevation 1: 2200-2550 m, elevation 2: 2550-2900 m, **P $<0.01, * \mathrm{P}<0.05$

ns: not significant. 
Table 2. The nutrient compositions (\%) of P. ferulacea (Mean \pm Std. Error) at different stages of maturity Dissimilar letters in each row indicate significant differences in the level of $\mathrm{P}<0.01^{* *}, 0.05^{*}$.

\begin{tabular}{|c|c|c|c|c|}
\hline & $\begin{array}{c}\text { flowering stage } \\
\text { and } 42 \text { days } \\
\text { after leaf } \\
\text { emergence }\end{array}$ & & $\begin{array}{c}\text { Seeding stage and } 62 \\
\text { days after leaf } \\
\text { emergence }\end{array}$ & \\
\hline & Fertile & Infertile & Fertile & Infertile \\
\hline DMD & $63.21 \pm 0.05^{b}$ & $68.25 \pm 0.11^{\mathrm{d}}$ & $59.09 \pm 0.07^{\mathrm{a}}$ & $64.83 \pm 0.12^{\mathrm{c}}$ \\
\hline $\mathbf{C P}$ & $24.49 \pm 0.11^{\mathrm{c}}$ & $26.02 \pm 0.25^{\mathrm{d}}$ & $16.67 \pm 0.13^{\mathrm{a}}$ & $17.66 \pm 0.1^{\mathrm{b}}$ \\
\hline WSC & $20.77 \pm 0.06^{\mathrm{b}}$ & $19.53 \pm 0.10^{\mathrm{a}}$ & $21.42 \pm 0.10^{\mathrm{d}}$ & $21.07 \pm 0.06^{\mathrm{c}}$ \\
\hline ADF & $39.38 \pm 0.28^{\mathrm{c}}$ & $36.36 \pm 0.09^{\mathrm{a}}$ & $41.76 \pm 0.08^{\mathrm{d}}$ & $38.30 \pm 0.11^{\mathrm{b}}$ \\
\hline $\mathrm{CF}$ & $20.52 \pm 0.14^{\mathrm{b}}$ & $18.42 \pm 0.12^{\mathrm{a}}$ & $23.49 \pm 0.11^{\mathrm{c}}$ & $20.34 \pm 0.052^{\mathrm{b}}$ \\
\hline NDF & $38.54 \pm 0.07^{\mathrm{c}}$ & $35.46 \pm 0.08^{\mathrm{a}}$ & $39.13 \pm 0.05^{\mathrm{c}}$ & $37.78 \pm 0.05^{\mathrm{b}}$ \\
\hline $\begin{array}{l}\text { ME(MJ kg }{ }^{-1} \\
\text { DM) }\end{array}$ & $8.74 \pm 0.01^{\mathrm{a}}$ & $9.60 \pm 0.02^{\mathrm{d}}$ & $8.04 \pm 0.01^{b}$ & $9.02 \pm 0.02^{\mathrm{c}}$ \\
\hline
\end{tabular}

3.3. The interaction effects of phenology, elevation and individuals on forge quality

Two-way ANOVA revealed that there was a significant effect for phenology and individual treatments $\left(F_{1,1} ; p<\right.$ $0.01)$. The effect of elevation was significant only for $\mathrm{CP}\left(F_{1,1}=8.983 ; p<0.05\right)$ and $\mathrm{NDF}\left(F_{1,1}=4.743 ; p<\right.$ $0.05)$. A significant phenology $\times$ individual interaction was observed, except for $\mathrm{CP}\left(F_{1,1}=3.728 ; p<0.05\right)$ and $\operatorname{NDF}\left(F_{1,1}=0.016 ; p<0.05\right)$ (Table 4).

The elevation $\times$ individual interaction $\left(F_{1,1} ; p<0.01\right)$ was not significant and the phenology $\times$ elevation interaction significantly affected WSC $\left(F_{1,1}=7.43 ; \mathrm{p}<\right.$ $0.05)$ and $\operatorname{ADF}\left(F_{1,1}=16.896 ; p<0.01\right)$. The phenology $\times$ elevation $\times$ individual interaction was significant for $\operatorname{DMD}\left(F_{1,1}=5.74 ; p<0.01\right)$ and $\operatorname{ME}\left(F_{1,1}\right.$
$=5.461 ; p<0.01)$ (Table 4). Between fixed factors, phenology had the highest effect and the elevation $\times$ individual interaction had the lowest effect for nutrient composition parameters (Table 4). These results indicated that quality of $P$. ferulacea forage depend on the stage of maturation at harvest date and type of individual. Based on nutrient data from field-collected aerial parts, younger plants recorded lower DM content but greater nutritional value. Demanet et al (2015) reported that high protein levels were observed in temperate regions pastures of Chile, when the plants have vegetative state with low level of dry matter and fiber, which transforms the forage in a high nutritional feed and a good digestibility value. Marshall et al (2002b) showed that $P$. ferulacea can be described as a high-energy food stuff that is comparable in value to legumes. 
Consequently, differences in the forage quality of this species when grown with alfalfa are likely to be small (Coskun, 2004).

Table 2 shows that both phenology and individual treatments had significant effects on the total nutrient composition of the above-ground biomass of the species. The effect of the phenology $\times$ individual interaction on nutrient composition was significantly higher than for other interactions (Table 4). Phenology had the greatest effect and elevation had the lowest effect on forage quality parameters. This indicates that phenology and plant factors can play important roles in determining foraging preferences.
It appeared that the decrease in DMD, $\mathrm{CP}$ and $\mathrm{ME}$ was related to an increase in ADF, NDF and CF contents and to the proportion of stem to whole plant as the plant matures. Thus, forage quality of plants has directly proportion to $\mathrm{DMD}, \mathrm{CP}$ and $\mathrm{ME}$ and inversely proportion to ADF (Uniyal et al., 2005; Valipoor Dastenai et al. 2012). This result is consistent with the findings by Temel et al (2015). The forage quality of infertile plants was greater than for fertile plants because the leaf/stem ratio of fertile plants of $P$. ferulacea was greater than for the infertile plants at both growth stages.

Table 3. Quality characteristics of forage with different type of plants at two maturity stages

\begin{tabular}{|c|c|c|c|c|c|c|c|c|}
\hline $\begin{array}{l}\text { Type of } \\
\text { plant }\end{array}$ & stage & DMD & $\overline{C P}$ & WSC & ADF & $\overline{C F}$ & NDF & $\overline{\text { ME }}$ \\
\hline \multirow{3}{*}{$\mathrm{F}$} & flowering & 63.215 & 24.5 & 20.775 & 39.385 & 20.515 & 38.545 & 8.745 \\
\hline & seeding & 59.1 & 16.67 & 21.435 & 41.765 & 23.5 & 39.135 & 8.045 \\
\hline & $\begin{array}{l}42 \mathrm{~d} \text { after } \\
\text { leaf } \\
\text { emergence }\end{array}$ & 68.25 & 26.015 & 19.535 & 36.365 & 18.42 & 35.42 & 9.605 \\
\hline $\mathrm{InF}$ & $\begin{array}{l}62 \mathrm{~d} \text { after } \\
\text { leaf } \\
\text { emergence }\end{array}$ & 64.84 & 17.66 & 21.075 & 38.305 & 20.355 & 37.795 & 9.02 \\
\hline s.e.d. ${ }^{I}$ & & 0.088 & 0.173 & 0.109 & 0.291 & 0.175 & 0.084 & 0.014 \\
\hline s.e.d. ${ }^{\text {II }}$ & & 0.161 & 0.266 & 0.105 & 0.145 & 0.133 & 0.099 & 0.028 \\
\hline s.e.d. ${ }^{\mathrm{III}}$ & & 0.121 & 0.274 & 0.106 & 0.292 & 0.185 & 0.107 & 0.020 \\
\hline s.e.d. ${ }^{\mathrm{V}}$ & & 0.138 & 0.161 & 0.108 & 0.142 & 0.118 & 0.073 & 0.024 \\
\hline sig & & $* *$ & $* *$ & ** & ** & $* *$ & $* *$ & $* *$ \\
\hline
\end{tabular}

s.e.d.I between mean of fertile individuals

s.e.d.II between mean of infertile individuals

s.e.d.III between mean of maturity stage 1

s.e.d.V between mean of maturity stage 2

$* * \mathrm{P}<0.01$ 


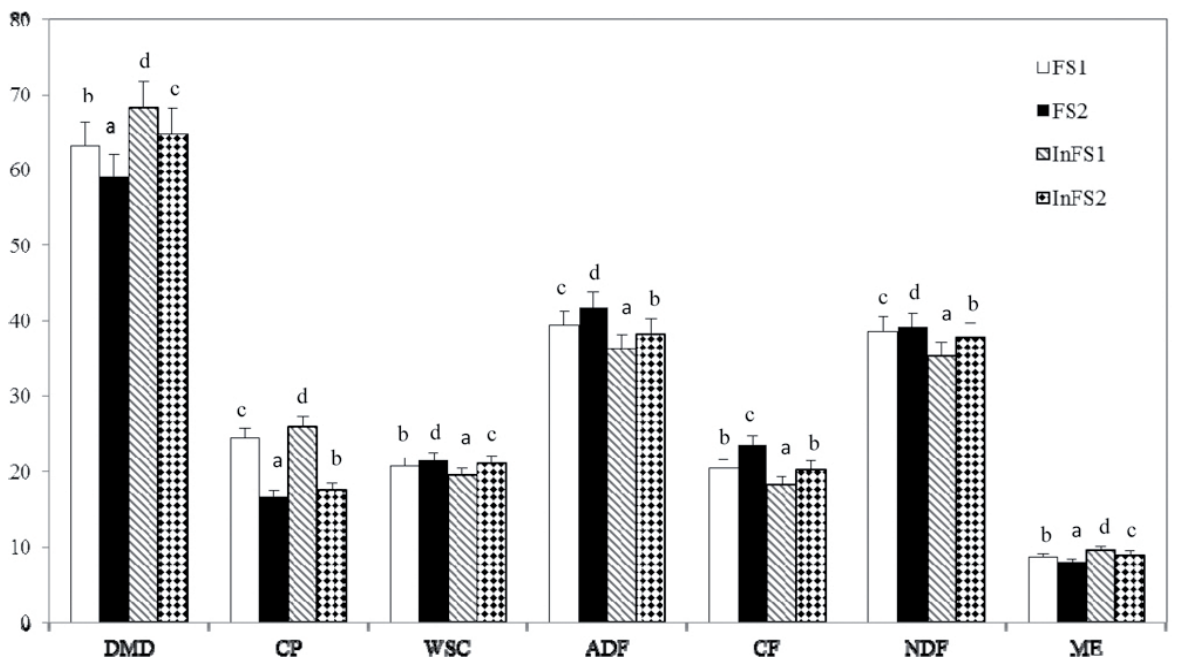

Figure 2. Comparison between the nutrient content (means $\pm \mathrm{SE}$ ) of FS1: the fertile plant in stage 1 or flowering, FS2: the fertile plant in stage 2 or seeding, InFS1: the infertile plant in stage 1 or 42 days after leaf emergence, InFS2: the infertile plant in stage 2 or 62 days after leaf emergence stage. $N=6$, Dissimilar letters indicate significant differences, (Tukey's post hoc test, $\mathrm{P}<0.01$ ).

The difference in forage quality of $P$. ferulacea between elevations was relatively small, although a significant difference was observed for DMD, WSC and ME, as only elevation treatments led to an increase in WSC and decrease in NDF contents. These differences were not generally observed at stage 1 . This appears to be the result of the relatively low elevation range of this in the sampling (700 m).

The WSC content increased as the elevation increased and was lower overall for infertile plants than for fertile plants. This agrees with the findings of Cazzato et al (2011). This difference may result from the existence of flowers and seeds in the fertile plants. WSC content in pre-ensiled forage allows assessment of the available supply of energy for lactic acid production during ensiling, and therefore is an important measurement for studies involving this forage.
Insufficient WSC will inhabit fermentation, while excess WSC provides substrate for undesirable organisms during storage and feed-out (d 2000).

The lowest and highest ME was related to fertile plant in stage $2\left(8.07 \mathrm{MJ} \mathrm{kg}^{-1} \mathrm{DM}\right)$ and infertile plant in stage 1 (9.60 $\left.\mathrm{MJ} \mathrm{kg}^{-1} \mathrm{DM}\right)$, respectively. The required ME for animal production with respect to animal unit weight in Iran (that is $50 \mathrm{Kg}$ ) (Arzani 2009) and MAFF proposed equation $(\mathrm{MEm}=1.4+0.09 *$ 50) (MAFF 1984) is 5.9 (MJ kg-1 DM). So, select the most appropriate harvest date and type of plant showed considerable difference for $\mathrm{ME}\left(\mathrm{MJ} \mathrm{kg}^{-1}\right.$ DM) and was affordable economically.

In general, differences between nutrient values were found for both fertile and infertile plants in the flowering stage (Table 2, Figure 2) and seeding stage (Table 3 , Figure 2). The rapidly-growing leaves from plants in the early phonological stages are generally rich in nitrogen and digestible energy (Crawley, 1983). 
Growth stage had a strong effect on forage quality of P. ferulacea. DMD, CP, ME contents at stage 1 were significantly greater and $\mathrm{CF}, \mathrm{NDF}$ and $\mathrm{ADF}$ were significantly lower than at stage 2 for both fertile plants and infertile plants. Kudo (1991) have found that plant phenology and associated quality changes over the growing season are expected to be most pronounced in strongly seasonal habitats, because of limitations set by the length of the growing season.
This is also in agreement with the findings of Gulsene et al (2004). Not recommended for two reasons not to harvest $P$. ferulacea before the flowering stage: soil erosion and; decreasing the success of breeding. Further study is clearly required for differences occurring between fertile and infertile plants to: (i) assess potential yield and quality at different sites; (ii) consider feeding experiments with dairy sheep and; (iii) examine economic factors.

Table 4. Statistical analysis of the main and mutual effects of phenology, elevation and individualon nutrient content (DMD, CP, WSC, ADF, NDF, CF, ME) of P. ferulacea. ${ }^{* *} \mathrm{P}<0.01, * \mathrm{P}<0.05$

\begin{tabular}{|c|c|c|c|c|c|c|c|c|}
\hline Factor & & DMD & $\mathbf{C P}$ & WSC & ADF & $\mathrm{CF}$ & NDF & ME \\
\hline \multirow[t]{4}{*}{ Phenology } & d.f. & 1,1 & 1 & 1 & 1 & 1 & 1 & 1 \\
\hline & Fratio & 2068.327 & 3542.848 & 327.4 & 50208.06 & 30978.66 & 37202.58 & 2013.051 \\
\hline & $\begin{array}{l}\text { Mean } \\
\text { Square }\end{array}$ & 85.051 & 392.931 & 7.271 & 4442.577 & 2537.927 & 1360.219 & 2.458 \\
\hline & Significance & $* *$ & $* *$ & $* *$ & $* *$ & $* *$ & $* *$ & $* *$ \\
\hline \multirow[t]{3}{*}{ elevation } & d.f. & 1 & 1 & 1 & 1 & 1 & 1 & 1 \\
\hline & $F$ ratio & 0.146 & 8.983 & 4.165 & 0.064 & 2.2 & 4.743 & 0.123 \\
\hline & $\begin{array}{l}\text { Mean } \\
\text { Square }\end{array}$ & 0.006 & 0.996 & 0.093 & 0.006 & 0.18 & 0.173 & 0.00 \\
\hline \multirow[t]{4}{*}{ individual } & $\begin{array}{c}\text { Significance } \\
\text { d.f. }\end{array}$ & ns & $*$ & ns & $\mathrm{ns}$ & ns & $*$ & ns \\
\hline & $F$ ratio & 4236.413 & 85.094 & 172.548 & 137.534 & 565.332 & 1612.837 & 4144.724 \\
\hline & $\begin{array}{l}\text { Mean } \\
\text { Square }\end{array}$ & 174.205 & 9.438 & 3.832 & 12.17 & 46.315 & 58.969 & 5.06 \\
\hline & Significance & $* *$ & $* *$ & $* *$ & $* *$ & $* *$ & $* *$ & $* *$ \\
\hline \multirow[t]{4}{*}{$\begin{array}{c}\text { phenology * } \\
\text { elevation }\end{array}$} & d.f. & 1 & 1 & 1 & 1 & 1 & 1 & 1 \\
\hline & $F$ ratio & 0.973 & 0.023 & 7.43 & 16.896 & 0.886 & 0.037 & 1.106 \\
\hline & $\begin{array}{l}\text { Mean } \\
\text { Square }\end{array}$ & 0.04 & 0.003 & 0.165 & 1.495 & 0.073 & 0.001 & 0.001 \\
\hline & Significance & ns & ns & $*$ & $* *$ & ns & ns & ns \\
\hline \multirow[t]{4}{*}{$\begin{array}{l}\text { phenology * } \\
\text { individual }\end{array}$} & d.f. & 1 & 1 & 1 & 1 & 1 & 1 & 1 \\
\hline & $F$ ratio & 18.045 & 3.728 & 52.901 & 171.968 & 34.031 & 0.016 & 16.724 \\
\hline & $\begin{array}{l}\text { Mean } \\
\text { Square }\end{array}$ & 0.742 & 0.413 & 1.175 & 15.216 & 2.788 & 0.001 & 0.02 \\
\hline & Significance & $* *$ & ns & $* *$ & $* *$ & $* *$ & ns & $* *$ \\
\hline \multirow[t]{3}{*}{$\begin{array}{l}\text { elevation * } \\
\text { individual }\end{array}$} & d.f. & 1 & 1 & 1 & 1 & 1 & 1 & 1 \\
\hline & $F$ ratio & 1.819 & 0.625 & 0.568 & 0.5 & 0.034 & 0.182 & 1.966 \\
\hline & $\begin{array}{l}\text { Mean } \\
\text { Square }\end{array}$ & 0.075 & 0.069 & 0.013 & 0.044 & 0.003 & 0.007 & 0.002 \\
\hline \multirow{5}{*}{$\begin{array}{l}\text { phenology * } \\
\text { elevation * } \\
\text { individual }\end{array}$} & Significance & ns & ns & ns & ns & ns & ns & ns \\
\hline & d.f. & 1 & 1 & 1 & 1 & 1 & 1 & 1 \\
\hline & Fratio & 5.74 & 1.673 & 3.026 & 4.381 & 0.86 & 0.055 & 5.461 \\
\hline & $\begin{array}{l}\text { Mean } \\
\text { Square }\end{array}$ & 0.236 & 0.186 & 0.067 & 0.388 & 0.07 & 0.002 & 0.007 \\
\hline & Significance & $*$ & ns & ns & ns & ns & ns & * \\
\hline
\end{tabular}




\section{Conclusions}

Factors analyzed in this study showed that both phenological stage and type of individual were effectible for harvesting in terms of nutritional value, but elevation could not be a considerable parameter for forage compared to other factors. When forage quantity is considered, it was determined that infertile plants at 42 days after leaf emergence stage was the most suitable for livestock feed. However as quality losses are little in fertile and infertile species at maturation stage 2 , it was stated that both individuals are suitable for feeding in means of fulfilling the nutrition requirements of grazing animals. All the prangos species naturally growing in these areas could also supply a considerable amount of forage with quality compared to conventional fodder resources. As a result, these species can play an important role as an alternative forage resource for livestocks in winter.

\section{Acknowledgements}

This work was supported by Iran National Science Foundation Science deputy of presidency (INSF).

\section{References}

Abrams, S.M., Barton, F.E., Blosser, T.H., Clark, D.H., Windham, W.R. 1989. 'Near Infrared Reflectance Spectroscopy ( NIRS): Analysis of Forage Quality'. Agricultural Research Service. US, No 643.

Ackerly, D. D., Dudley, S. A., Sultan, S. E., Schemitt, J., Coleman, S. J. 2000. The evolution of plant ecophysiology traits: Recent advances and future directions. Bioscience.11, 979-995.

Ajani, Y., Ajani, A., Jenny, M. C., Mark, F.W., Stephen, R. D. 2008. Phylogenetic analysis of nr DNAITS sequences reveals relationships within five groups of Iranian Apiaceae subfamily Apioideae. TAXON 57. 2, 383-401.

Arzani, H. 2009. Forage Quality and Daily Requirement of Grazing Animal. University of Tehran Press, Tehran, Iran. 354pp.

Arzani, H., Pouzas, H., Motamedi, J., Mirakhorli, R., Niknejad, S.A. 2012. Effects of phenological stages on forage quality of five rangeland species in semi-steppe rangeland of jashlobar semnan. Iranian J. Range and Desert Res. 19, 3(48): 384394.

Ayres, D., Tamm, C., Raphael, R., Shamma, M. 1994. Dictionary of Natural Products.Chapman \& Hall. London.

Cazzato, E., Laudadio, V., Corleto, A., Tufarelli, V. 2011. Effects of harvest date, wilting and inoculation on yield and forage quality of ensiling safflower (Carthamus tinctorius L.) biomass. J. Sci. Food Agric. 91, 2298-2302.

Cherney, D. J. R. 2000. Characterization of forages by chemical Analysis. Forage Evaluation in Nutrition. Oxford, London.

Crawley, M.J. 1983. Herbivory. The dynamics of animal-plantinteractions. Blackwell Scientific Publications. Oxford, Great Britain.

Corson, D.C., Waghorn, G.C., Ulyatt, M. J., Lee, J. 1999. NIRS: Forage analysis and livestock feeding. Proceedings of the New Zealand Grassland Association. 61, 127-132.

Coskun, B., Gulsen, N., Umucalilar, H.D. 2004. The nutritive value of Prangos ferulacea. Grass and Forage Science. 59, 15-9.

Demanet, R., Mora, M.L., Herrera, M.A., Miranda, H., Barea, J.M. 2015. Seasonal variation of the productivity and quality of permanent pastures in Adisols of temperate regions. Journal of Soil Science and Plant Nutrition. 15 (1), 111-128. 
Dierig, D.A., Adama, N.R., Mackey, B.E., Dahlquist, G.H., Coffelt, T.A. 2006. Temperature and elevation effects on plant growth, development and seed production of two Lesquerella species. Industrial Crops and Products. 24, 17-25.

Genctan, T. 2012. Tarimsal Ekoloji (Agricultural Ecology). University of Namik Kemal Publishing, Tekirdag, Turkiye.

Ghahreman, A. 1997. Flora of Iran. Seconded Tehran Research Institute of Forests and Rangelands. Tehran, Iran.

Gheitoori, M., Malakpoor, B., Jafari, M., Jalili, A. 1997. Investigation of ecological characteristic of Prangos spp. in Kermanshah province. Journal of Pajohesh and Sazandegi. 32, 32-35.

Gulsen, N., Coskun, B., Umucalılar, H. D., Dural H. 2004. Prediction of nutritive value of a native forage, Prangos uechritzii, using of in situ and in vitro measurements. Journal of Arid Environments. $56,167-179$.

MAFF. 1984. Energy allowances and feeding systems for ruminants. ADAS references book, HMSO, London.

Milošević, M., N. Milošević, N., IGlišić, I. 2013. Agronomic properties and nutritional status of plum trees (Prunus domestica L.) influenced by different cultivars. Journal of Soil Science and Plant Nutrition. 13(3), 706-714.

Moghimi, J., Ansari, V. 2004. Introduction some of the range important species of suitable for the development and rangelands. Aron publication, Tehran, Iran, 132-138 pp.

Mozaffarian, V. 1996. A Dictionary of Iranian Plant Names. Farhang Moaser Publishers, Tehran, Iran, 332-342 pp.

Oktay, G., Temel, S. 2015. Determination of annual fodder value of Ebu Cehil (Calligonum polygonoides L. ssp. comosum (L'Hér.) shrub. J.
Agricultural Faculty of Gaziosmanpasa University. $32,30-36$.

Panahi, F., Assareh, M.H., Jafari, M., Jafari, A., Arzani, H., Tavili, A., Zandi Esfahan, E. 2012. Phenological effects on forage quality of Salsola arbuscula, Salsola orientalis and Salsolato mentosa in three habitats in the central part of Iran. Middle East J. Sci. Res. 11(6): 800-807.

Razavi, S.M. 2012. Chemical composition and some allelopathic aspects of essential oils of (Prangos ferulacea L.) Lindl at different stages of growth. J. Agric.Sci. Tech. 14, 349-56.

Rechinger, K.H., Hedge, I.C. 1987. Flora Iranica. Vol, 162. Akademische Druke Verlgsanstalt, Graz.

Reuther, K. 2013. Spatial and temporal flower presentation in Apiacea-Apioideae. Dissertation, Department of Biology, the Johannes Gutenberg University.

Sefidkon, F., Khajavi, M., Malackpour, B. 1998. Analysis of the Oil of Prangos ferulacea (L.) Lindl. J. Essent. Oil Res. 10, 81-82.

CSIRO. 1990. Standing Committee on Agriculture, Australia.

Temel, S., Surme, M., Tan, M. 2015. Effects of growth stages on the nutritive value of speccific halophyte species in saline grasslands. J. Anim. Plant Sci. 25, 1419-1428.

Ulyatt, M.J., Lee, J., Corson, D. 1995. Assessing feed quality. Ruakura Farmers Conference. 47, 59-62.

Uniyal, S.K., Awasthi, A., Rawat, G.S. 2005. Biomass availability and forage quality of Eurotia ceratoides Mey in the rangelands of Changthang, easthern Ladakh. Current Sciencs. 89, 201-205.

Valipoor Dastenai, M., Mirhadi, M.J., Mehrani, A. 2012. The study and comparison of 3 foxtail millet (Setaria italica L.) cultivars in different phenological stages in Karaj Region. Tec. J. Engin. and App. Sci. 2(3): 62-68. 